\title{
Characterization of epidermal growth factor receptor in human endometrial cells in culture
}

\author{
H. Watson ${ }^{1}$, S. Franks ${ }^{2}$ and R. C. Bonney ${ }^{1, *}$ \\ ${ }^{1}$ Unit of Metabolic Medicine and ${ }^{2}$ Department of Obstetrics and Gynaecology, \\ St Mary's Hospital Medical School, Imperial College of Science, Technology and Medicine, London
} W2 $1 P G, U K$

\begin{abstract}
The aim of the study was to determine the binding characteristics of the epidermal growth factor (EGF) receptor in isolated human endometrial glands and stromal cells in culture. Stromal cells and glands were obtained from endometrial tissue by collagenase dispersion followed by sieve filtration. They were plated into 24-well multiwell plates in Ham's F10 medium supplemented with $5 \%$ fetal calf serum and used at $70-80 \%$ confluence. Scatchard analysis revealed a single class of high-affinity binding sites in both cell types with apparent dissociation constants of $1.17 \pm 0.6(n=15)$ and $1.20 \pm 0.3(n=8) \mathrm{nmol} \mathrm{l}^{-1}$ for stromal cells and glands, respectively. The concentration of receptors was higher in stromal cells than in glands, $719 \pm 377(n=16)$ and $310 \pm 177(n=8) \mathrm{fmol} \mathrm{mg}^{-1}$ protein, respectively. Epidermal growth factor labelled with ${ }^{125} \mathrm{I}$ was displaced from the receptor by EGF and transforming growth factor $\alpha$, but not insulin, insulin-like growth factor, fibroblast growth factor, or platelet-derived growth factor. Binding was shown to be dependent on time and temperature. Downregulation of the receptor was demonstrated by preincubating cells with $5 \mathrm{nmol}$ EGF $\mathrm{I}^{-1}$, which reduced receptor concentrations by $75 \%$. $12-\mathrm{O}-$ Tetradecanoylphorbol-13-acetate decreased the affinity of the receptor for EGF changing the dissociation constant from 1.8 to $3.9 \mathrm{nmol}^{-1}$. A suitable system for investigating the regulation of this receptor in human endometrium was established.
\end{abstract}

\section{Introduction}

Several studies have implicated epidermal growth factor (EGF) and its receptor in the regulation of uterine function, particularly with respect to uterine cell growth and differentiation. Receptors for EGF have been identified in the uterus of several species including rats (Mukku and Stancel, 1985a), guinea-pigs (Sorrentino and Hendrix, 1984), pigs (Zhang et al., 1992) and humans (Hofman et al., 1984; Taketani and Mizuno, 1988; Bonaccorsi et al., 1989; Chegini et al., 1992). Furthermore, immunocytochemical staining of human endometrium has revealed the presence of receptors in both the glandular epithelial and stromal cells (Berchuck et al., 1989; Smith et al., 1991; Chegini et al., 1992).

Cyclical variation in EGF receptor concentrations in the human endometrium, as demonstrated by Taketani and Mizuno (1988), Bonaccorsi et al. (1989) and Troche et al. (1991) has indicated that EGF and its receptor mediate the effects of oestradiol and EGF receptor concentrations are increased in rats in vivo by treatment with oestradiol (Mukku and Stancel, 1985b).

Most studies of the EGF receptor in the human uterus, with the exception of a mixed cell culture study by Taketani and Mizuno (1991), have been carried out on tissue homogenates.

*Correspondence.

Received 6 December 1993.
The aim of the present study was therefore to establish and validate a ligand-binding assay for the measurements and characterization of the EGF receptor in human endometrium using a cell culture system of isolated stromal and glandular epithelial cells. Such a system would enable the regulation of EGF receptor function to be investigated in the two types of cell.

\section{Materials and Methods}

\section{Materials}

All reagents except culture media were, unless otherwise stated, obtained from Sigma Chemical Co (Poole). Culture media, trypsin/EDTA, fetal calf serum and 'Linbro' multiwell plates were obtained from Flow Laboratories Ltd, Rickmansworth. Hank's balanced salt solution (HBSS) was always supplemented with $0.1 \mathrm{mg}$ kanamycin $\mathrm{ml}^{-1}$ and $10 \mathrm{U}$ nystatin $\mathrm{ml}^{-1}$. Ham's F10 culture medium was supplemented with $5 \%$ fetal calf serum, 2 mmol glutamine $1^{-1}$, $5 \mathrm{mg}$ insulin $\mathrm{ml}^{-1}$, and $0.1 \mathrm{mg}$ kanamycin $\mathrm{ml}^{-1}$ (Ham's F1O supplemented medium).

\section{Collection of endometrium and preparation of cell cultures}

Endometrium was obtained from 18 women (12 in the proliferative phase and six in the secretory phase) undergoing 
hysterectomy for nonmalignant conditions (menorrhagia, fibroids or prolapse). The consent of the patients was obtained and the study was approved by the local Ethics Committee (Parkside Health Authority). Tissue for culture was transported to the laboratory in HBSS in a sterile container on ice. A portion of endometrium was sent to the Histopathology Laboratory for examination by light microscopy and endometrial dating.

Stromal cells and intact glands were isolated by enzymatic dispersion using $0.125 \%$ collagenase (Type XI) using the method described by Bonney et al. (1991). The method used did not exclude other cell types that may have been present in the stromal cell preparation, as separation was achieved on the basis of size. Use of CDI4, a specific monoclonal antibody, showed that $3-5 \%$ of cultured cells are monocytes or macrophages (Taketani and Mizuno, 1991). Isolated stromal cells were either plated directly into 24-well multiwell plates (well diameter of $16 \mathrm{~mm}$ ) at a density of $2 \times 10^{5}$ cells per well, in $0.5 \mathrm{ml}$ Ham's F10 supplemented medium, or seeded for subsequent passage into $75 \mathrm{~cm}^{2}$ flasks. The flasks contained $12 \mathrm{ml}$ Ham's F10 supplemented medium, but in these flasks the serum concentration was increased to $10 \%$. The glands were evenly distributed between half the number of wells required for the stromal cells; consistent plate coverage was obtained by this procedure. The cells attached within $24 \mathrm{~h}$, after which blood cells and debris were removed by washing three times with HBSS. The primary cell cultures were maintained in Ham's F10 supplemented medium and used at $70-80 \%$ confluence (usually on day 4). The cells in flasks were grown to confluence and then detached using $0.05 \%$ trypsin and $0.02 \%$ EDTA. They were then subcultured in $75 \mathrm{~cm}^{2}$ flasks until required.

Passaged cells were detached as described above and plated in multiwell plates at a density of $2.5 \times 10^{5}$ cells per well and maintained as described for primary cell cultures. Passaged cells were not used beyond the fourth passage. The use of passaged cells enabled us to increase the number of cells available from a single piece of tissue for large experiments where this was necessary. This procedure also resulted in improved plating efficiency as the cells were free from the contaminating cell debris and blood cells present in primary dispersions. Primary cells were used for initial binding studies in which comparisons were made between glands and stromal cells and for smaller experiments, whereas passaged stromal cells were used for larger experiments. No differences were observed between primary and passaged cells with respect to the $K_{\mathrm{d}}$ value and the number of binding sites.

Before measuring EGF receptor concentrations, the cell cultures were washed three times with HBSS and then maintained for $24 \mathrm{~h}$ in Ham's F10 medium without serum but supplemented with $10 \mathrm{mmol}$ glutamine $\mathrm{l}^{-\mathrm{I}}, 10 \mathrm{mg}$ insulin $\mathrm{ml}^{-1}$, $100 \mathrm{ng}$ hydrocortisone $\mathrm{ml}^{-1}, 10 \mathrm{mg}$ transferrin $\mathrm{ml}^{-1}, 25 \mathrm{ng}$ sodium selenite $\mathrm{ml}^{-1}$ and $0.1 \mathrm{mg}$ kanamycin $\mathrm{ml}^{-1}$. The cells were washed three times with $1 \mathrm{ml}$ ice-cold PBS, pH 7.5, before using as described below.

\section{Iodination of $E G F$}

Epidermal growth factor $(5 \mu \mathrm{g})$, prepared in $5 \mu$ liodination buffer $\left(0.5 \mathrm{~mol}\right.$ sodium acetate buffer $\left.\mathrm{l}^{-1}, \mathrm{pH} 6.0\right)$, was incubated with $1 \mathrm{mCi}{ }^{125} \mathrm{I}$ and $10 \mu \mathrm{g}$ lactoperoxidase (in $50 \mu \mathrm{l}$ iodination buffer) for $6 \mathrm{~min}$. The reaction was terminated with $100 \mu \mathrm{l}$ saturated tyrosine and $100 \mu \mathrm{l}$ PBS containing $2 \%$ BSA. The reactants were mixed, transferred to a PD10 column previously equilibrated with $25 \mathrm{ml}$ iodination buffer and $20 \times 1 \mathrm{ml}$ fractions were collected. ${ }^{125} \mathrm{I}$-labelled EGF eluted in fractions $3-5$ and the mean ( $\pm \mathrm{SD}$ ) specific activity was 92.2 ( \pm 18.2) $\mu \mathrm{Ci} \mu \mathrm{g}^{-1}$ EGF for the five preparations used.

\section{Binding studies}

Scatchard analysis. Primary cell cultures were incubated at $37^{\circ} \mathrm{C}$ for $30 \mathrm{~min}$ in Ham's F10 medium supplemented only with $0.1 \% \mathrm{BSA}$ and containing a range of concentrations of ${ }^{125}$ I-labelled EGF of between 0.3 and $8.0 \mathrm{nmol} \mathrm{1}^{-1}$. Nonspecific binding was determined in the presence of a 500-fold excess of unlabelled EGF. The reaction was terminated by the addition of $1 \mathrm{ml}$ of ice-cold PBS and the cells were then washed twice with $0.5 \mathrm{ml}$ ice-cold PBS. The cells were solubilized with $5 \mathrm{~mol}$ sodium hydroxide $1^{-1}(200 \mu \mathrm{l})$ and then transferred to polypropylene tubes and radioactivity measured in a HewlettPackard $\gamma$ counter. Results were transformed by the method of Scatchard (1949), and then expressed as fmol EGF bound $\mathrm{mg}^{-1}$ protein; protein was measured by the method of Lowry et al. (1951).

Binding specificity. Primary stromal cell cultures were incubated with 5 nmol ${ }^{125}$ I-labelled EGF $1^{-1}$ in $100 \mu$ l of Ham's F10 and $0.1 \% \mathrm{BSA}$, together with either unlabelled EGF, transforming growth factor $\alpha$ (TGF- $\alpha$ ), insulin, insulin-like growth factor (IGF), fibroblast growth factor (FGF), or platelet-derived growth factor (PDGF) at a concentration of $0-1.4 \mu \mathrm{mol} \mathrm{l}^{-1}$. All estimations were carried out in triplicate for $30 \mathrm{~min}$ at $37^{\circ} \mathrm{C}$. The reaction was terminated with $1 \mathrm{ml}$ ice-cold $\mathrm{PBS}$ and the cells were washed twice with $0.5 \mathrm{ml}$ PBS. The cells were then solubilized as indicated above.

Dependence of binding on time and temperature. Passaged stromal cell cultures were incubated for up to $180 \mathrm{~min}$ at temperatures of 4,21 and $37^{\circ} \mathrm{C}$ with $5 \mathrm{nmol}^{125} \mathrm{I}$-labelled EGF l $^{-1}$ in $100 \mu \mathrm{l} \mathrm{Ham}$ 's F10 medium containing $0.1 \%$ BSA. At time points between 0.25 and $180 \mathrm{~min}$, the reaction was terminated by the addition of $1 \mathrm{ml}$ of ice-cold PBS and the cells were washed twice with $0.5 \mathrm{ml}$ PBS. Estimations were carried out in triplicate at each time point, with nonspecific binding determined in duplicate in the presence of a 500-fold excess of unlabelled EGF. The cells were then solubilized as indicated above.

Surface binding and internalization of the EGF receptor. Passaged stromal cell cultures were incubated with $5 \mathrm{nmol}{ }^{125} \mathrm{I}$ labelled EGF $l^{-1}$ in $100 \mu \mathrm{l} \mathrm{Ham}$ 's F10 medium containing $0.1 \%$ $\mathrm{BSA}$ at temperatures of 4,21 and $37^{\circ} \mathrm{C}$ for up to $180 \mathrm{~min}$. The reaction was terminated by the addition of $1 \mathrm{ml}$ of ice-cold PBS and the cells were then washed twice with $0.5 \mathrm{ml} P B S$ at time points between 0.25 and $180 \mathrm{~min}$. All estimations were carried out in triplicate and nonspecific binding was determined in duplicate at each time point in the presence of a 500 -fold excess of unlabelled EGF. Surface-bound ${ }^{125}$ I-labelled EGF was 


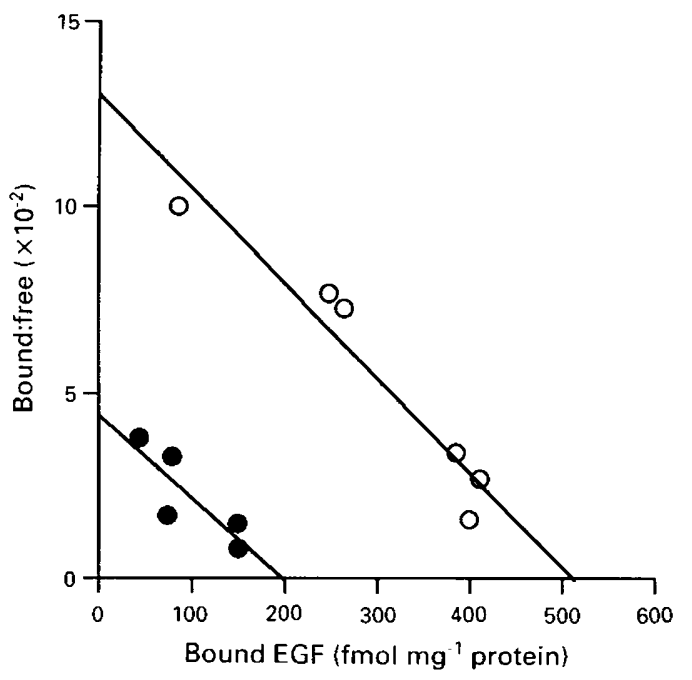

Fig. 1. Scatchard analysis of binding of ${ }^{125} \mathrm{I}$-labelled epidermal growth factor $(E G F)$ to human endometrial glands $(0)$ and stromal cells $(O)$ in culture,

removed by incubation for $4 \mathrm{~min}$ at $4^{\circ} \mathrm{C}$ with $200 \mu \mathrm{l} 0.5 \mathrm{~mol}$ sodium chloride $1^{-1}$, titrated to $\mathrm{pH} 2.5$ with acetic acid. The incubation medium was transferred to polystyrene tubes and the radioactivity measured. The cells were then solubilized with $200 \mu \mathrm{l} 5 \mathrm{~mol}$ sodium hydroxide $\mathrm{I}^{-1}$ for $30 \mathrm{~min}$ at $37^{\circ} \mathrm{C}$ to recover internalized ${ }^{125}$ I-labelled EGF, which was then transferred to polypropylene tubes and radioactivity measured.

Downregulation of the EGF receptor. Primary stromal cell cultures were preincubated with unlabelled EGF at concentrations of between 0 and $5 \mathrm{nmol} \mathrm{l}^{-1}(n=5)$ for $1 \mathrm{~h}$ at $37^{\circ} \mathrm{C}$ in $500 \mu \mathrm{l}$ Ham's F10 medium with $0.1 \%$ BSA. The cells were then washed twice with $1 \mathrm{ml}$ of ice-cold PBS and then incubated for a further $2 \mathrm{~h}$ at $4^{\circ} \mathrm{C}$ in $500 \mu \mathrm{l}$ medium without EGF. The cells were then incubated with $100 \mu \mathrm{l}$ medium containing $5 \mathrm{nmol}$ ${ }^{125}$ I-labelled EGF $1^{-1}$ in triplicate. Nonspecific binding was determined in duplicate in the presence of a 500 -fold excess of unlabelled EGF. The reaction was terminated by the addition of $1 \mathrm{ml}$ of ice-cold PBS and the cells were washed twice with $0.5 \mathrm{ml}$ PBS. They were then solubilized as indicated above.

Regeneration of the EGF receptor. Primary stromal cell cultures were incubated for $30 \mathrm{~min}$ at $37^{\circ} \mathrm{C}$ in the presence or absence of 5 nmol EGF $1^{-1}$ in Ham's F10 medium with $0.1 \%$ BSA. The cells were then washed three times with ice-cold PBS and incubated at $4^{\circ} \mathrm{C}$ for $2 \mathrm{~h}$ without EGF. Concentrations of the EGF receptor were then assessed either immediately or following overnight incubation $(20 \mathrm{~h})$ in serum-free defined medium.

Effect of 12-O-tetradecanoylphorbol-13-acetate (TPA) on EGF receptor binding and affinity. Passaged stromal cells were incubated in the presence or absence of 10 and $100 \mathrm{nmol} \mathrm{TPA} 1^{-1}$ in Ham's F10 and $0.1 \%$ BSA for $30 \mathrm{~min}$ at $37^{\circ} \mathrm{C}$. Scatchard analysis was then carried out as previously described. (a)

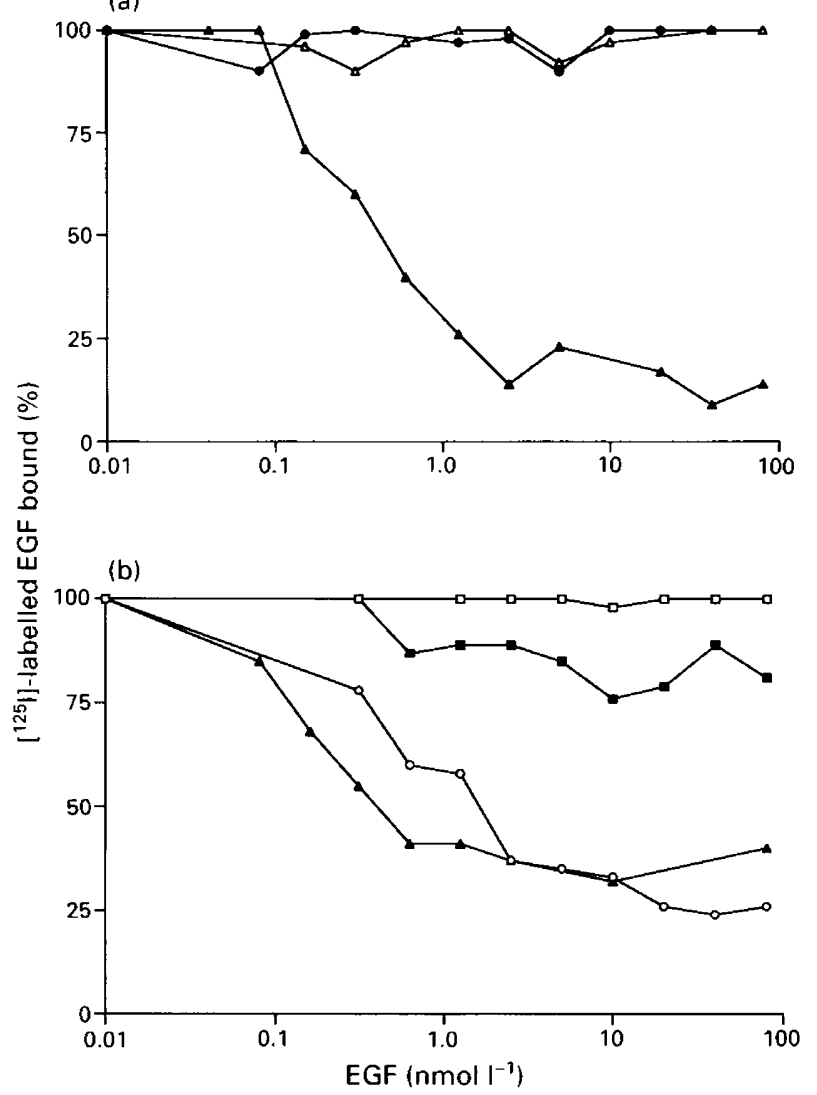

Fig. 2. Specificity of binding of ${ }^{125}$ I-labelled epidermal growth factor (EGF) to human endometrial stromal cells in culture. (a) EGF (৯), fibroblast growth factor (FGF; •), platelet-derived growth factor

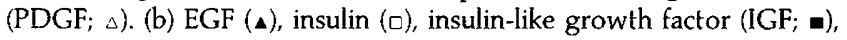
transforming growth factor $\alpha$ (TGF- $\alpha ; 0)$.

\section{Results}

Specific binding of ${ }^{125}$ I-labelled EGF occurred in both the stromal and epithelial cell cultures. Scatchard analysis of binding data revealed a single class of high-affinity receptor. Mean $( \pm \mathrm{SD})$ dissociation constants of $1.17( \pm 0.6) \mathrm{nmol} \mathrm{l}^{-1}$ $(n=15)$ and $1.20( \pm 0.3) \mathrm{nmol} \mathrm{l}^{-1}(n=8)$ were obtained for stromal cells and glands, respectively. Receptor concentrations were higher in stromal cells than in glands, with values of $719 \pm 377(n=16)$ and $310 \pm 177(n=8) \mathrm{fmol} \mathrm{mg}^{-1}$ protein, respectively (Fig. I). There was no difference between proliferative and secretory phase tissue with respect to the number of receptors measured in either glands or stromal cells. The values obtained for stromal cells were $779 \pm 385 \mathrm{fmol} \mathrm{mg}^{-1}$ protein $(n=11)$ (proliferative phase) and $586 \pm 362 \mathrm{fmol} \mathrm{mg}^{-1}$ protein $(n=5)$ (secretory phase), and for glands the values were $298 \pm 107 \mathrm{fmol} \mathrm{mg}^{-1}$ protein $(n=6)$ (proliferative phase) and $350 \pm 199 \mathrm{fmol} \mathrm{mg}^{-1}(n=2)$ protein (secretory phase).

TGF- $\alpha$ and unlabelled EGF displaced ${ }^{125}$ I-labelled EGF from the receptor in a dose-dependent manner. Insulin, IGF, FGF or PDGF did not affect binding (Fig. 2).

The time and temperature dependence of binding are shown in Fig. 3. In this experiment, binding at $4^{\circ} \mathrm{C}$ reached a maximum 


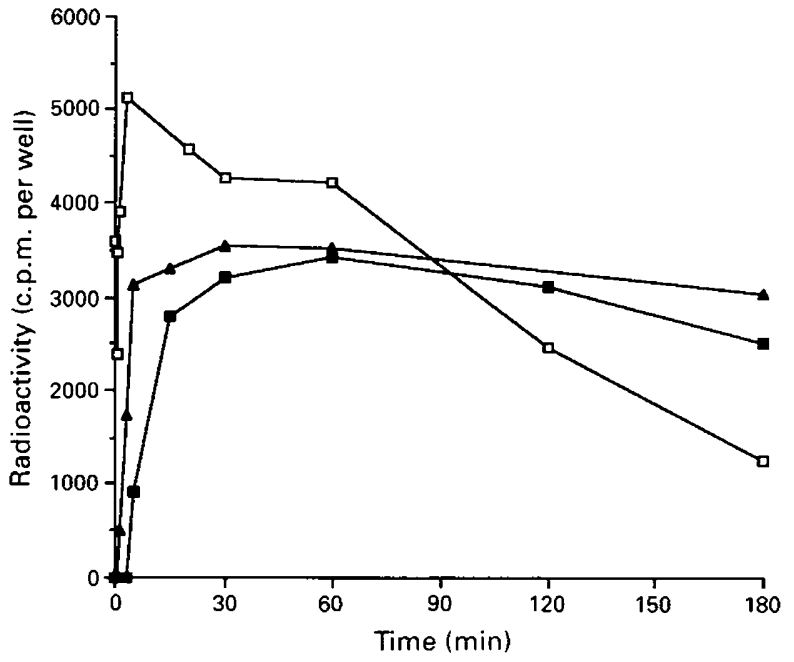

Fig. 3. Surface binding and internalization of ${ }^{125} \mathrm{I}$-labelled epidermal growth factor at (a) $4^{\circ} \mathrm{C},(\Delta) 21^{\circ} \mathrm{C}$ and (口) $37^{\circ} \mathrm{C}$ in human endometrial stromal cells in culture.

after $30 \mathrm{~min}$ and then remained constant during the course of the experiment $\left(3 \mathrm{~h}\right.$ ) (Fig. 3). At $21^{\circ} \mathrm{C}$, binding was more rapid, reaching a maximum between 10 and $30 \mathrm{~min}$, and thereafter remaining constant. The response was even more rapid at $37^{\circ} \mathrm{C}$, when maximum binding had occurred by $5 \mathrm{~min}$. The maximum binding at $37^{\circ} \mathrm{C}$ was greater than at $4^{\circ}$ and $21^{\circ} \mathrm{C}$, but declined during the course of the experiment. Separate consideration of surface-bound and internalized ${ }^{125}$ I-labelled EGF revealed that at $4^{\circ} \mathrm{C}$, no internalization took place following binding of ${ }^{125} \mathrm{I}$-labelled EGF to the surface of the cell. At $21^{\circ} \mathrm{C}$, surface binding was more rapid and internalization occurred after $10 \mathrm{~min}$, causing a decrease in the number of receptors available for binding. Surface binding occurred even more rapidly at $37^{\circ} \mathrm{C}$ and internalization commenced after $1 \mathrm{~min}$ (Fig. 4).

Pretreatment of stromal cell cultures with EGF resulted in a dose-dependent decrease in the number of receptors subsequently available for binding, demonstrating a downregulation of the receptor (Fig. 5). A concentration of $1 \mathrm{nmol}$ EGF $\mathrm{I}^{-1}$ caused a loss of $50 \%$ of the surface receptors. Preincubation with $5 \mathrm{nmol} \mathrm{EGF} 1^{-1}$ diminished receptor concentrations by $75 \%$, but receptors were restored after $20 \mathrm{~h}$ of incubation in the absence of EGF (Fig. 6).

Incubation with $10 \mathrm{nmol} \mathrm{TPA} \mathrm{^{-1 }}$ for 30 min before EGF receptor assay caused a decrease in the affinity of the receptor for EGF (Fig. 7). The dissociation constant increased from $1.8 \mathrm{nmol} 1^{-1}$ to $3.9 \mathrm{nmol} \mathrm{l}^{-1}$ in the presence of TPA and the number of receptors was unchanged.

\section{Discussion}

We demonstrated the presence of a single, high-affinity binding site for EGF in endometrial glands and stromal cells maintained in short-term culture. The $K_{d}$ value was shown to be the same in the two cell types and is in keeping with that found by other groups for human endometrial homogenates
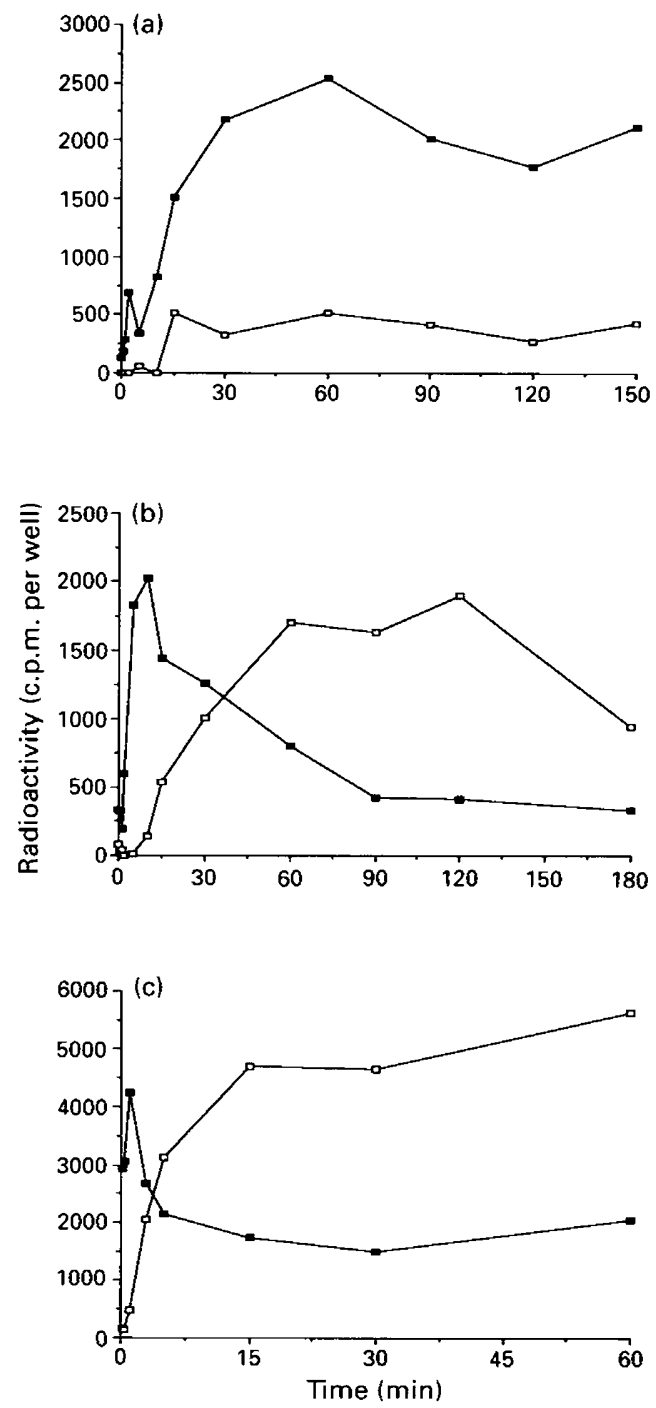

Fig. 4. Time and temperature dependence of binding of ${ }^{125}$ I-labelled epidermal growth factor (EGF) to human endometrial stromal cells in culture at (a) $4^{\circ} \mathrm{C}$, (b) $21^{\circ} \mathrm{C}$, (c) $37^{\circ} \mathrm{C}$. (a) Surface-bound EGF receptors (口) internalized EGF receptors.

(Taketani and Mizuno, 1988; Bonaccorsi et al., 1989; Smith et al., 1991) and for pig (Zhang et al., 1992) and guinea-pig endometrial cells (Sorrentino and Hendrix, 1984). The relative concentrations of receptors between the different cell types is a matter of controversy. Immunocytochemical staining of the EGF receptor in human endometrium by Smith et al. (1991) revealed a higher concentration in the glands, while Chegini et al. (1992) and Berchuck et al. (1989) found no difference in the intensity of staining between the two cell types. Our studies have shown higher concentrations of receptors in the stromal cells, irrespective of whether a correction is made for either protein or DNA content (data not shown). When Zhang et al. (1992) studied porcine endometrial cells in culture, they also found fewer EGF receptors in the glands than in the stromal cells.

Stromal cells actively proliferate in culture. However, glands, cultured on a plastic surface appear morphologically different 


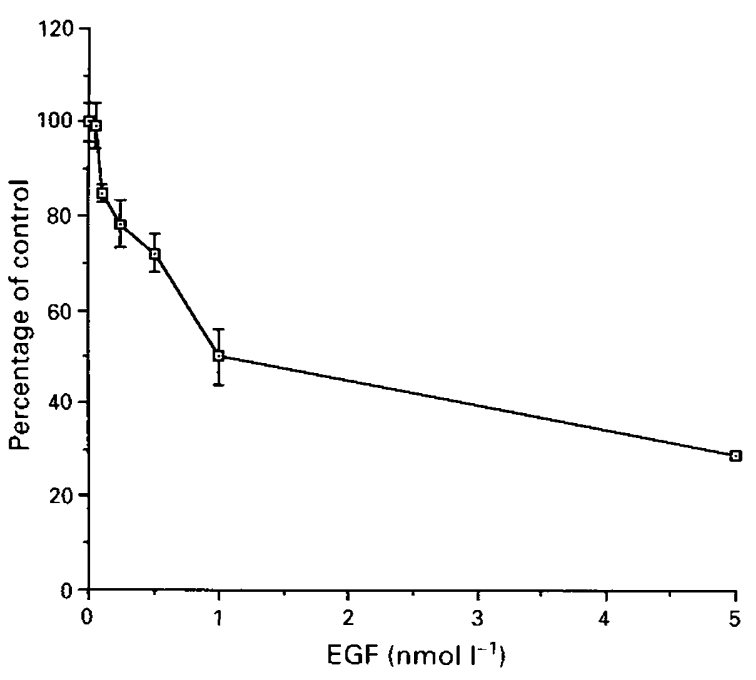

Fig. 5. Binding of ${ }^{125}$ I-labelled epidermal growth factor (EGF) following incubation for $30 \mathrm{~min}$ of human endometrial stromal cells with increasing concentrations of unlabelled EGF. Results are expressed as percentages of control, where control is designated as the number of receptors measured without preincubation.

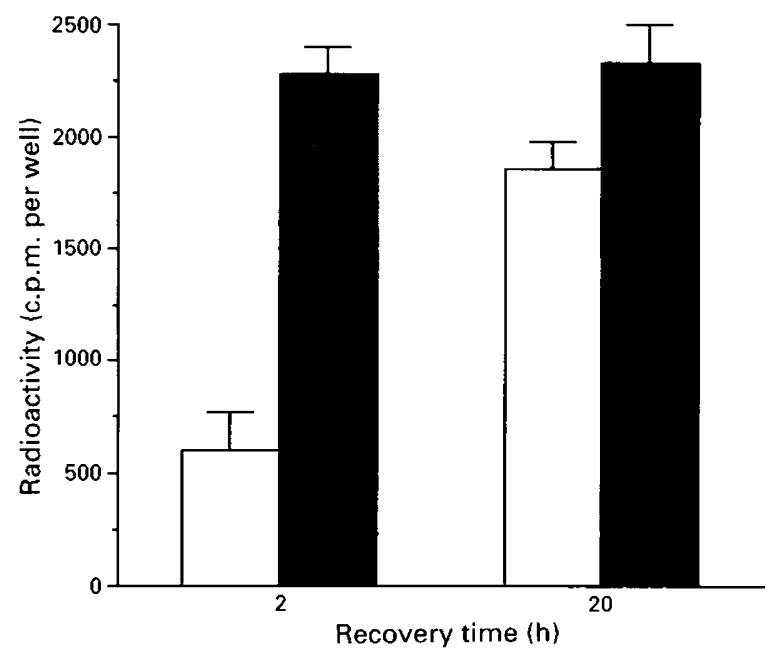

Fig. 6. Comparison of binding of ${ }^{125}$ I-labelled epidermal growth factor (EGF) to human endometrial stromal cells measured 2 and $20 \mathrm{~h}$ after a 30 min incubation ( $\square$ ) with EGF or ( $\square$ ) without EGF.

from those observed in situ, becoming flattened and fusiform and losing their surface microvilli (Kirk et al., 1978). Strauss and Gurpide (1991) reported a moderate proliferation of glands in culture, but Marshburn et al. (1992) were unable to demonstrate proliferation in glands grown on the biomatrix Matrigel. The relative lack of glandular EGF receptors may therefore be associated with their inability to proliferate in this cell culture system and may not reflect concentrations in vivo.

There is considerable sequence homology between EGF and TGF- $\alpha$, and TGF- $\alpha$ is known to bind to the EGF receptor. Our studies have confirmed that TGF- $\alpha$ binds to the EGF receptor in human endometrial stromal cells, causing an equivalent

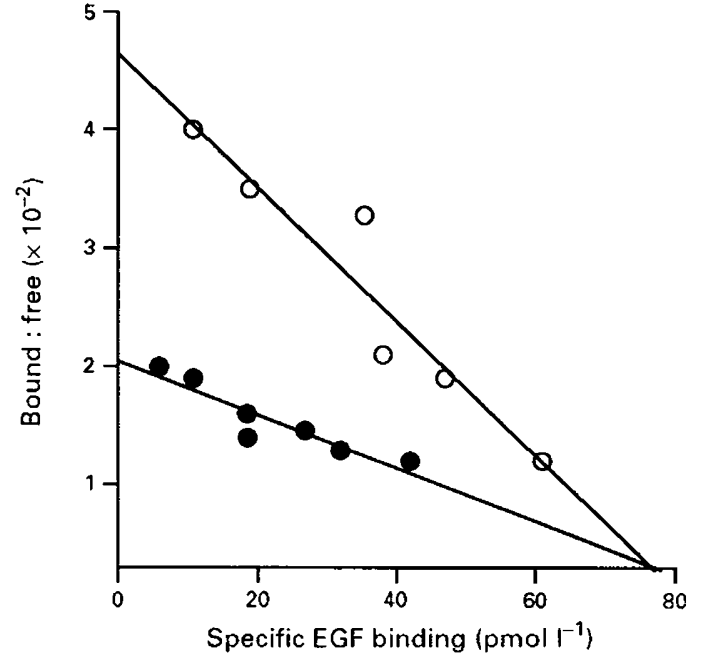

Fig. 7. Scatchard analysis of the effect of 12-O-tetradecanoylphorbol13-acetate (TPA) on binding of ${ }^{125}$ I-labelled epidermal growth factor (EGF) to human endometrial stromal cells $(-)$ with or $(O)$ without TPA. The $K_{\mathrm{d}}$ value in the absence of TPA was $1.8 \mathrm{nmol} \mathrm{l}^{-1}$ and in the presence of TPA it was $3.9 \mathrm{nmol} \mathrm{l}^{-1}$.

displacement of ${ }^{125}$ I-labelled EGF to that caused by unlabelled EGF. The growth factors insulin, IGF, PDGF and FGF did not displace EGF from the receptor.

The internalization and consequent downregulation of the receptor upon binding to EGF is dependent on time and temperature (Carpenter et al., 1975). The full complement of receptors is restored to the surface within $20 \mathrm{~h}$ of downregulation (Aharohov et al., 1978). Our findings indicate that, as in other tissues, EGF can moderate the level of its own receptor in the human endometrium, imposing an internal control on effects such as proliferation.

Phorbol esters are known to inhibit the binding of ${ }^{125} \mathrm{I}$ labelled EGF, and Brown et al. (1979) have demonstrated that in Swiss 3 T3 cells TPA causes a decrease in the affinity of the cellular receptors for EGF without changing the number of binding sites. Davis and Czeck (1984) suggested that the mechanism of TPA action on the response of cells to EGF may be partly mediated by phosphorylation of the EGF receptor. The enzyme responsible for this phosphorylation is protein kinase C (Davis and Czeck, 1986). In our studies, TPA reduced the affinity of the EGF receptor in endometrial stromal cells, suggesting that protein kinase $\mathrm{C}$ and its activators may play a role in mediating the mitogenic effect of EGF in the endometrium.

We have established and validated the measurement of the EGF receptor in primary cultures of human endometrial glands and stromal cells, thus providing a suitable system for further investigation into the regulation of the EGF receptor in the human endometrium.

The authors gratefully acknowledge the assistance of the operating theatre staff of the Samaritan Hospital for Women, London, in the collection of endometrial tissue. The work was supported by the Wellcome Trust and the Band Trust. 


\section{References}

Aharohov A, Pruss RM and Herschman HR (1978) Epidermal growth factor, relationship between receptor regulation and mitogenesis in 3T3 cells Journal of Biological Chemistry 253 3970-3977

Berchuck A, Soisson AP, Olt GJ, Soper JT, Clarke-Pearson DL, Bast RC Jr and McCarty KS Jr (1989) Epidermal growth factor receptor expression in normal and malignant endometrium American Joumal of Obstetrics and Gynecology 161 1247-1252

Bonaccorsi G, Pansini F, Segala V, Bagni B, Bergamini CM and Mollica G (1989) Modification of number and affinity of endometrial EGF receptors during the menstrual cycle European Journal of Obstetrics, Gynaecology and Reproductive Biology 33 177-182

Bonney RC, Beesley JS and Franks S (1991) Release of arachidonic acid from human endometrial cells in culture mediated by calcium ionophore (A23187) or fluoride Journal of Reproduction and Fertility 93 449-460

Brown KD, Dicker P and Rozengurt E (1979) Inhibition of epidermal growth factor binding to surface receptors by tumour promoters Biochemical and Biophysical Research Communications 86 1037-1043

Carpenter G, Lembach KJ, Morrison MM and Cohen S (1975) Characterisation of the binding of ${ }^{125} \mathrm{I}$-labelled epidermal growth factor to human fibroblasts Journal of Biological Chemistry 250 4297-4304

Chegini N, Rossi MJ and Masterson BJ (1992) Platelet-derived growth factor (PDGF), epidermal growth factor (EGF), and EGF and PDGF $\beta$ receptors in human endometrial tissue: localisation and in vitro action Endocrinology 130 2373-2385

Davis RJ and Czech MP (1984) Tumor-promoting phorbol diesters mediate phosphorylation of the epidermal growth factor receptor Journal of Biological Chemistry $2598545-8549$

Davis RJ and Czech MP (1986) Inhibition of the apparent affinity of the epidermal growth factor receptor caused by phorbol diesters correlates with phosphorylation of threonine-654 but not other sites on the receptor Biochemical Journal $233435-441$

Hofmann GE, Rao ChV, Barrows GH, Schultz GS and Sanfilippo JS (1984) Binding sites for epidermal growth factor in human uterine tissues and leiomyomas Joumal of Clinical Endocrinology and Metabolism 73 882-887
Kirk D, King RJB, Heyes J, Peachey L, Hirsch PJ and Taylor RWT (1978) Normal human endometrium in cell culture In Vitro 14 651-662

Lowry OH, Rosebrough NJ, Farr AL \& Randall RJ (1951) Protein measurement with the Folin phenol reagent Joumal of Biological Chemistry 193 263-275

Marshburn PB, Head JR, MacDonald PC and Casey ML (1992) Culture characteristics of human endometrial glandular epithelium throughout the menstrual cycle: modulation of deoxyribonucleic acid synthesis by $17 \beta$-estradiol and medroxyprogesterone acetate. American Journal of Obstetrics and Gynecology 167 1888-1898

Mukku VR and Stancel GM (1985a) Receptors for epidermal growth factor in the rat uterus Endocrinology 117 149-154

Mukku VR and Stancel GM (1985b) Regulation of epidermal growth factor receptor by estrogen Journal of Biological Chemistry $2609820-9824$

Scatchard G (1949) The attraction of proteins for small molecules and ions Annals of the New York Academy of Sciences 51 660-672

Smith K, LeJeune S, Harris AH and Rees MCP (1991) Epidermal growth factor receptor in human uterine tissues Human Reproduction 6 619-622

Sorrentino JM and Hendrix MJC (1984) EGF receptor binding studies in endometrial cell culture Life Sciences 34 1769-1774

Strauss JF and Gurpide $\mathbf{E}$ (1991) The endometrium: regulation and dysfunction. In Reproductive Endocrinology, pp 309-356 Eds SC Yen and RB Jaffe. W.B. Saunders, Philadelphia

Taketani, Y and Mizuno M (1988) Cyclic changes in epidermal growth factor receptor in human endometrium during the menstrual cycle Endocrinologica Japonica 35 19-25

Taketani Y and Mizuno M (1991) Evidence for direct regulation of epidermal growth factor receptors by steroid hormones in human endometrial cells Human Reproduction 6 1365-1369

Troche V, O'Connor DM and Schaudies RP (1991) Measurement of human epidermal growth factor receptor in the endometrium during the menstrual cycle American Joumal of Obstetrics and Gynecology 5 1499-1503

Zhang Z, Krause M and Davis DL (1992) Epidermal growth factor receptors in porcine endometrium: binding characteristics and the regulation of prostaglandin $\mathrm{E}$ and $\mathrm{F}_{2 a}$ production Biology of Reproduction 46 932-936 